\title{
Phytophthora Contamination in a Nursery and Its Potential Dispersal into the Natural Environment
}

Agnes V. Simamora, Centre for Phytophthora Science and Management, School of Veterinary and Life Sciences, Murdoch University, Perth, WA, 6150, Australia; and Faculty of Agriculture, University of Nusa Cendana, Kupang, Indonesia; Trudy Paap and Kay Howard, Centre for Phytophthora Science and Management, School of Veterinary and Life Sciences, Murdoch University; Michael J. C. Stukely, Science and Conservation Division, Department of Parks and Wildlife, Bentley Delivery Centre, WA 6983, Australia; and Giles E. St. J. Hardy and Treena I. Burgess, ${ }^{\dagger}$ Centre for Phytophthora Science and Management, School of Veterinary and Life Sciences, Murdoch University

\begin{abstract}
A detailed site investigation of a eucalypt nursery suffering disease losses revealed the causal agent to be Phytophthora boodjera. The pathogen was detected in vegetation surrounding the nursery production area, including the lawn, under the production benches during the growing season, and, most importantly, from plant debris in used trays. However, it was not found in the container substrate, water supplies, or production equipment or on the workers themselves. The sterilization methods used by the nursery were shown to be ineffective, indicating that a more rigorous method was required.

Boiling trays for $15 \mathrm{~min}$ or steaming at $65^{\circ} \mathrm{C}$ for 60 min eradicated $P$. boodjera. This pathogen was more pathogenic to the eucalypts tested in their early seedling stage than $P$. cinnamomi. Tracing of out-planting to revegetation sites showed that $P$. boodjera was able to spread into the environment. Dispersal via out-planting to native vegetation may affect seedling recruitment and drive long-term shifts in native plant species. Inadequate nursery hygiene increases the risk of an outbreak and can limit the success of biosecurity efforts as well as damage conservation efforts.
\end{abstract}

Increased plant trade facilitates the movement of invasive plant pathogens (Brasier 2008), and Phytophthora spp. are of particular significance (Jung et al. 2016; Pérez-Sierra and Jung 2013). Phytophthora spp. can move readily through the nursery supply chain when infected plants are asymptomatic (Parke and Grünwald 2012; PérezSierra and Jung 2013). Diseases caused by Phytophthora spp. in nurseries are a worldwide problem (Bienapfl and Balci 2014) and are a direct threat to biodiversity.

In Western Australia, where there has been a longstanding concern about the presence of Phytophthora spp. Container-grown plants in 14 nurseries contained one or more Phytophthora spp. associated with rotted roots of 65 plant taxa (Hardy and Sivasithamparam 1988). Davison et al. (2006) found Phytophthora spp. in 10\% of the samples of potting substrate in 15 consignments of nursery-grown plants imported into Western Australia from other states in Australia. One Western Australia nursery was the source of eight different Phytophthora spp. (Hardy and Sivasithamparam 1988). There are many examples of the spread of Phytophthora spp. to natural areas from nurseries in Europe, South America, and the United States. The extent of the problem in Europe was highlighted by Jung et al. (2016), who estimated that there is an average of 3.6 Phytophthora spp. in each infested tree nursery and planting site. Clearly, in Europe, current nursery hygiene and control practices are not sufficient to eliminate the risk of spreading this damaging pathogen.

The dispersal of Phytophthora spp. from nurseries to revegetation plantings in previously noninfested areas may result in serious threats to biodiversity in natural ecosystems. A recent outbreak of dampingoff disease of young eucalypt seedlings, caused by Phytophthora boodjera A. V. Simamora \& T. I. Burgess, has been observed in a eucalypt seedling production nursery in Tincurrin, in southern Western Australia. This nursery produces seedlings principally for conservation plantings in, or adjacent to, natural ecosystems, or to increase the diversity of plant species in remnant native bush stands on farms. Reinfestation was occurring on site despite extensive

${ }^{\dagger}$ Corresponding author: T. I. Burgess; E-mail: tburgess@murdoch.edu.au

*The $\boldsymbol{e}$-Xtra logo stands for "electronic extra" and indicates that two supplementary tables are published online.

Accepted for publication 20 August 2017.

() 2018 The American Phytopathological Society preseason preparation to eradicate the pathogen. The Phytophthora database of the Department of Parks and Wildlife (DPaW) in Western Australia, which contains more than 44,000 records collected over 35 years, reveals only five recent records of $P$. boodjera not associated with nurseries. This, along with the findings of Simamora et al. (2015), implies that $P$. boodjera was probably introduced recently to Western Australia and, hence, is an ideal species for tracking from production nursery to the out-planting sites. This study presents a systematic sampling strategy to determine the possible sources of on-site contamination in the nursery to understand the epidemiology of $P$. boodjera and develop methods for its control within the nursery. In addition, targeted sampling was undertaken to determine the survival of $P$. boodjera in areas adjacent to the nursery and in the revegetation sites after the planting of potentially infected seedlings from the infested nursery.

\section{Materials and Methods}

The nursery is situated in the southeastern wheatbelt of Western Australia and has been operating since 1999, servicing the land care and revegetation needs of farmers, with a capacity of 4 million seedlings. The nursery (although not accredited) was designed along Nursery and Garden Industry Australia guidelines (NIASA 2013) and current best-practice management principles were followed.

A rigorous sampling regime was undertaken to determine potential sources of contamination. This was followed by an examination of pathogen survival within the nursery and within host tissue, the pathogen's ability to infect different plant species, and whether or not risk is heightened under waterlogged conditions. To help reduce ongoing infections, different sterilization techniques for reused trays were tested. The spread to the surrounding environment and tracing outplanting to the revegetation sites were also assessed.

Sample processing to detect Phytophthora spp. All plants, potting media, and debris were baited for the detection of possible Phytophthora spp. in 1-liter plastic containers (11.5 by 16.5 by $7.5 \mathrm{~mm}$; GENFAC Plastics Pty Ltd.), with five replicate containers for each sample.

Soil and substrate baiting. Samples (100 to $150 \mathrm{~g}$ ) were flooded with $350 \mathrm{ml}$ of deionized (DI) water, and bait leaves of Quercus suber, Q. ilex, Pimelea ferruginea, Poplar spp., Scholtzia involucrata, Hedera helix, Eucalyptus spp. (juvenile leaves), or Rosa officinalis, or Hibbertia scandens petals (availability depending on the season) were placed on the water surface. After 4 to 10 days at room temperature $\left(20\right.$ to $\left.29^{\circ} \mathrm{C}\right)$, the baits with lesions were blotted on paper towels, cut into 1- to 3-mm pieces, and plated on NARH Phytophthora selective medium. Per liter of deionized water, NARH contains $17 \mathrm{~g}$ of oxoid cornmeal agar, $1 \mathrm{ml}$ 
nystatin (Nilsat, Wyeth-Ayerst Australia Pty Ltd, Baulkham Hills, NSW), $100 \mathrm{mg}$ ampicillin sodium (Fisons Pty Ltd, Sydney, NSW), $10 \mathrm{mg}$ rifampcin (Rifadin, Hoechst Marion Roussel Australia Pty Ltd, Lane Cove, NSW), and $50 \mathrm{mg}$ hymexazol (Tachigaren, Sankyo Company, Toyota, Japan). The antibiotics were dissolved in sterile water and added to cooled agar (about $50^{\circ} \mathrm{C}$ ) prior to pouring into Petri dishes. Plates were maintained in the dark at room temperature and regularly observed for colonies typical of Phytophthora spp. Water samples $(500 \mathrm{ml})$ from the dams, rainwater tanks, and the potting shed drainage outlet were baited directly.

Filtering. Water samples (five samples of 1 liter each) were also filtered through $0.45-\mu \mathrm{m}$ pore filters (Whatman) with three replicate filters per sample. Filter papers were plated directly onto NARH for $24 \mathrm{~h}$ and removed; then, the plates were incubated at room temperature and observed daily.

Direct plating. Seedling roots were washed in tap water to remove potting substrate and blotted dry, with 1 - to $3-\mathrm{mm}$ pieces plated onto NARH. Insects were collected, squashed, and plated directly onto NARH medium. Plates were incubated for 7 to 10 days at room temperature and observed for colony morphology and structures consistent with Phytophthora spp.

The identity of Phytophthora isolates was confirmed by sequencing of the internal transcribed spacer gene region, as described previously (Simamora et al. 2015).

Sampling for Phytophthora spp. in and around the nursery. Over 3 years, the following sets of samples were collected at the start of seeding, throughout the growing season, and when the nursery was fallow after the seedlings had been dispatched (Fig. 1; Table 1).

Water supply. Water was sampled from taps, the dam, rainwater tanks, and the drainage outlet from the concrete floor of the potting shed. The water samples were tested in two ways. First, tap water and drainage outlet water was filtered. Second, water samples were collected from the surface of dams and rainwater tanks and from the potting shed drainage outlet and transported in 1-liter plastic containers, in cool boxes, to the laboratory for baiting and filtering within $24 \mathrm{~h}$.

Material adjacent to nursery area. Tree roots which had grown into the water tank or pond and those of adjacent mallee eucalypts (native remnants) were collected for direct plating, as described above. Soil, leaves, and litter from the mallees planted as a windbreak and vegetation (weeds, moss, and grass) close to the nursery floor area were collected and baited, as described above.

Equipment utilized in potting, storage, and handling area. Used seedling trays stacked and ready for reuse, gloves, tires, wheel barrows, loader, potting machine, and other machinery, as well as worker's hands, were scraped to remove old potting substrate, soil, and residual plant debris. At least $100 \mathrm{~g}$ of material from each source was bagged and transported to the laboratory for baiting.

Nursery production area. Soil from beneath benches and from the adjacent windbreak trees, together with potting substrate from healthy and diseased seedlings on the nursery benches, was baited. In addition, seedling roots, ants from under or near benches, and gnat larvae from pots of plants showing symptoms were also collected and directly plated, as described above.

Tray and potting mix sterilization treatments. The efficacy of various treatment methods for sterilization of trays was examined in three experiments: (i) testing of used nursery trays with and without container substrate, (ii) testing of the nursery's standard tray treatment, and (iii) testing of trays with seedlings grown in different container substrates and watered with different sources of water.

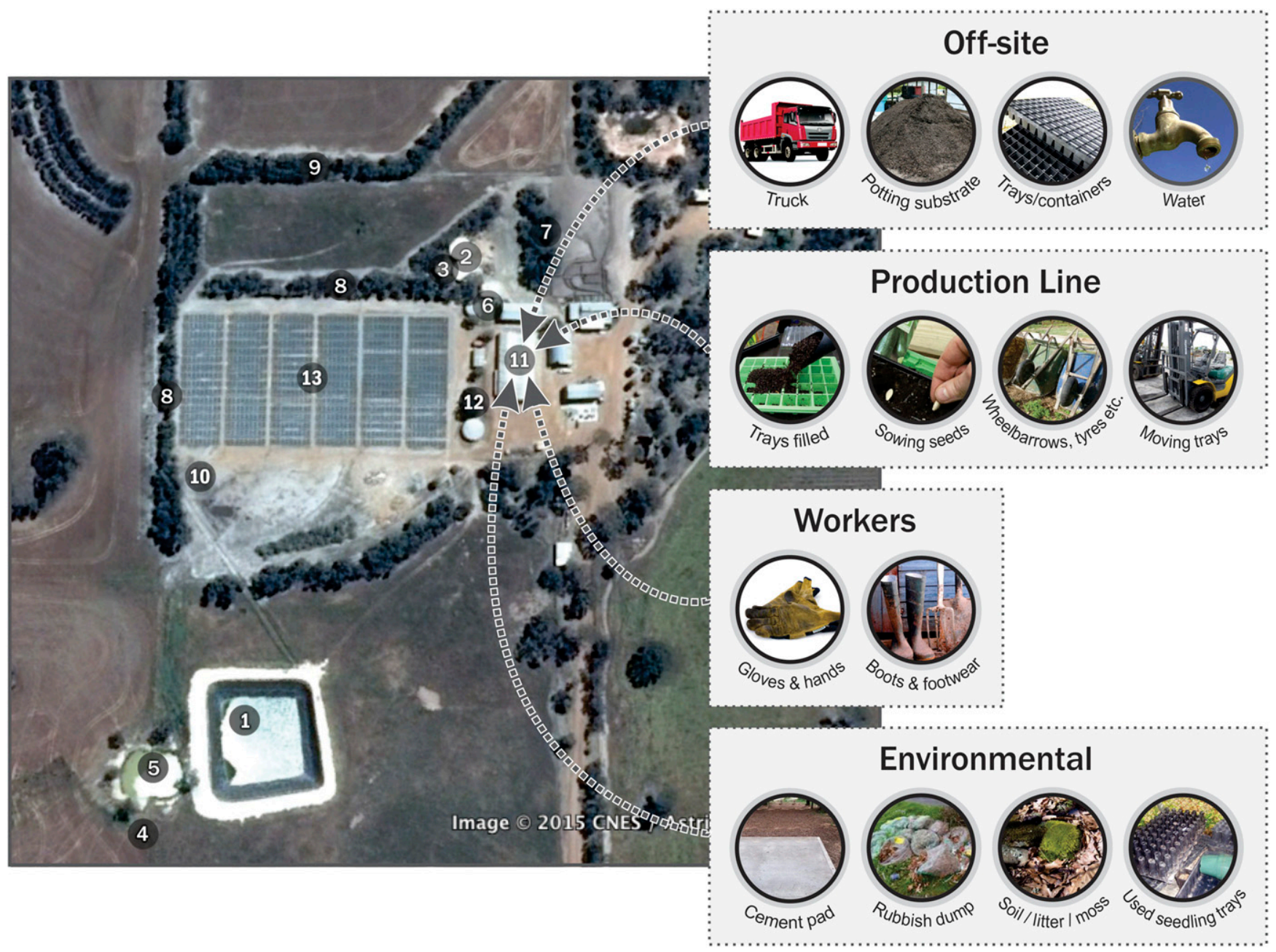

Fig. 1. Sampling locations and potential sources of contamination of Phytophthora boodjera at a native tree nursery, Tincurrin, Western Australia. The numbers correspond to the sampling locations listed in Table 1. 
Nursery trays with and without potting substrate. Ten control trays (untreated, used trays) were rinsed with DI water in a container and the water collected was baited for Phytophthora spp. (three replicate bait containers per tray). Nonsterilized container substrate from the nursery was also tested. Additional trays were pasteurized, with and without container substrate (10 replicates/treatment). Pasteurization was carried out at a maximum of $65^{\circ} \mathrm{C}$ for $1 \mathrm{~h}$. After 2 to 4 days, bait leaves with necrotic lesions were plated on NARH.

Standard on-site tray treatment. Trays in which high disease incidence had been observed in the seedlings were used for this study. Trays were emptied of container substrate and allowed to dry, as was normal nursery practice, and the following methods of tray disinfestation were tested: (i) immersion in water which was brought to the boil, then rapidly boiled for $15 \mathrm{~min}$; (ii) exposure to dry heat up to $65^{\circ} \mathrm{C}$; and (iii) soaking in biocide (Steri-maX [Agricorp] and didecyl dimethyl ammonium chloride at $120 \mathrm{~g} /$ liter) in a $0.1 \%$ solution for $10 \mathrm{~min}$. After the treatments, all trays were individually rinsed with DI water and the rinse water was collected and baited for Phytophthora spp. (three replicate bait containers per tray).

Testing of trays with seedlings grown in different container substrates and watered with different sources of water. This trial was conducted using three different types of trays (new trays, used trays known to have had high disease incidence, and boiled trays). The trays were sown with Eucalyptus loxophleba subsp. gratiae Benth and Banksia occidentalis $\mathrm{R}$. Br. in two different container substrates: composted pine bark medium supplied from the nursery and composted pine bark supplied by the $\mathrm{DPaW}$. The trays were watered daily using water from three different sources: rainwater (outside water supply, located approximately $3 \mathrm{~km}$ from the nursery, untreated rainwater), nursery treated water tank, and nursery rainwater. There were five replicate trays for each treatment. After 6 weeks, seedlings were removed and trays were emptied. Seedlings and potting substrates were baited as explained above.

Table 1. Recovery of Phytophthora boodjera from different materials sampled from various locations across the nursery site ${ }^{\mathrm{y}}$

\begin{tabular}{|c|c|c|c|c|}
\hline \multirow[b]{2}{*}{ Site } & \multirow[b]{2}{*}{ Material sampled } & \multicolumn{3}{|c|}{ Season $^{\mathrm{z}}$} \\
\hline & & Prep & Grow & Fallow \\
\hline \multicolumn{5}{|c|}{ Water supply } \\
\hline 1 & Dam water & $0 / 5$ & $\ldots$ & $\ldots$ \\
\hline 2 & Rain water tanks & $0 / 5$ & $\ldots$ & $\ldots$ \\
\hline 10 & Drainage water & $0 / 5$ & $3 / 5$ & $0 / 5$ \\
\hline 11 & Water from potting shed taps & $\ldots$ & $0 / 15$ & \\
\hline 11 & Drainage outlet from potting shed floor & $\ldots$ & $\ldots$ & $0 / 5$ \\
\hline \multicolumn{5}{|c|}{ Adjacent to nursery } \\
\hline 2 & Roots from water tank & $0 / 5$ & $\ldots$ & $\ldots$ \\
\hline 3 & Roots from eucalypt near water tank & $5 / 10$ & $\ldots$ & $2 / 10$ \\
\hline 4 & Roots of eucalypt near pond & $\cdots$ & $\ldots$ & $0 / 5$ \\
\hline 5 & Mud from pond & $\cdots$ & $\ldots$ & $0 / 5$ \\
\hline 5 & Roots from pond near nursery & $\ldots$ & $\ldots$ & $0 / 5$ \\
\hline 6 & Nursery lawn & $5 / 5$ & $\ldots$ & $2 / 5$ \\
\hline 7 & Soil from under trees (close) & $5 / 5$ & $\ldots$ & $4 / 10$ \\
\hline 8 & Leaves from adjacent long hedgerow & $\ldots$ & $\ldots$ & $0 / 40$ \\
\hline 8 & Litter from adjacent long hedgerow & $\ldots$ & $0 / 5$ & $0 / 20$ \\
\hline 8 & Soil from corner of adjacent hedgerow & $\ldots$ & $\ldots$ & $1 / 40$ \\
\hline 9 & Litter from adjacent trees - short hedge & $\ldots$ & $\ldots$ & $0 / 5$ \\
\hline 9 & Soil from secondary hedge trees & $\ldots$ & $\ldots$ & $2 / 5$ \\
\hline 11 & Vegetation close to potting shed floor & $\ldots$ & $\ldots$ & $0 / 20$ \\
\hline 12 & Eucalyptus near used tray storage area & $\ldots$ & $\ldots$ & $0 / 10$ \\
\hline \multicolumn{5}{|c|}{ Potting, storage, and handling } \\
\hline 11 & Seed & $-\mathrm{ve}$ & $\ldots$ & $\ldots$ \\
\hline 11 & Used trays (untreated) & $20 / 20$ & $\ldots$ & $\ldots$ \\
\hline 11 & Container substrate off delivery truck & $0 / 5$ & $\ldots$ & $\ldots$ \\
\hline 11 & Mud in front of soil shed & $0 / 5$ & $\ldots$ & $\ldots$ \\
\hline 11 & Soil from loader & $0 / 5$ & $\ldots$ & $\ldots$ \\
\hline 11 & Container substrate (different batches) & $0 / 20$ & $\ldots$ & $\ldots$ \\
\hline 11 & Steamed soil $\left(65^{\circ} \mathrm{C}\right)$ & $0 / 20$ & $\ldots$ & $\ldots$ \\
\hline 11 & Fingers of nursery workers & $0 / 5$ & $\ldots$ & $\ldots$ \\
\hline 11 & Gloves of nursery workers & $0 / 5$ & $\ldots$ & $\ldots$ \\
\hline \multicolumn{5}{|c|}{ Debris from } \\
\hline 11 & Container substrate shed after cleaning & $0 / 5$ & $\ldots$ & $\ldots$ \\
\hline 11 & Tray filling machine after cleaning & $0 / 5$ & $\ldots$ & $\ldots$ \\
\hline 11 & Adjacent to stored container substrate & $0 / 5$ & $\ldots$ & $\ldots$ \\
\hline 11 & Potting shed floor & $0 / 5$ & $\ldots$ & $\ldots$ \\
\hline 11 & Wheelbarrow shed & $0 / 5$ & $\ldots$ & $\ldots$ \\
\hline 11 & Bench top in potting shed & $0 / 5$ & $\ldots$ & $\ldots$ \\
\hline 11 & Tray racks & $0 / 5$ & $\ldots$ & $\ldots$ \\
\hline \multicolumn{5}{|c|}{ Nursery production area } \\
\hline 13 & Soil under benches from nine locations & $0 / 15$ & $5 / 50$ & $0 / 45$ \\
\hline 13 & $\begin{array}{l}\text { Cotyledon stage seedlings ( } 2 \text { weeks old) } \\
\text { E. loxophleba subsp. lissophloia }\end{array}$ & $\cdots$ & $-\mathrm{ve}$ & $\cdots$ \\
\hline 13 & $\begin{array}{l}\text { E. loxophleba subsp. lissophloia (bulk } \\
\text { sample) }\end{array}$ & $\cdots$ & + ve & $\cdots$ \\
\hline 13 & Ants & $\ldots$ & $0 / 15$ & $\ldots$ \\
\hline 13 & Fungal gnat larvae & $\ldots$ & $0 / 10$ & $\ldots$ \\
\hline
\end{tabular}

${ }^{y}$ Number of positive recoveries is shown over the number of samples tested; +ve and-ve denote presence or absence, respectively, in multiple samples that were too numerous to count.

${ }^{\mathrm{z}}$ Season of sample collection. Prep $=$ preparation for planting $($ October to November), Grow $=$ growing season (October to June), and Fallow $=$ July to October. 
Persistence of naturally produced oospores. A trial of heat treatments to eradicate oospores of $P$. boodjera living inside the root debris in used trays was undertaken. Inoculum was prepared as follows: $400 \mathrm{ml}$ of vermiculite substrate ( $400 \mathrm{mg}$ of vermiculite, $4 \mathrm{~g}$ of millet seed, and $240 \mathrm{ml}$ of V8 broth) was placed into a 500-ml Erlenmeyer flask, sealed with nonabsorbent cotton wool, and covered with aluminum foil. The flasks were autoclaved three times at $121^{\circ} \mathrm{C}$ for $20 \mathrm{~min}$ over three consecutive days, then inoculated once the substrate had cooled. Inoculum per flask consisted of one Petri dish $(9 \mathrm{~cm}$ in diameter) of V8 agar plugs colonized for 7 days by $P$. boodjera isolate (VHS 26806; recovered from soil in 2012, Tincurrin, Western Australia). Flasks were shaken, placed inside ziplock plastic bags, and incubated at $20^{\circ} \mathrm{C}$ in the dark. The flasks were shaken every 3 days for the first 2 weeks to evenly spread the inoculum. Five-week-old inocula were rinsed with DI water to remove excess nutrients (Matheron and Mircetich 1985) immediately before inoculation of the container substrate. Successful colonization of the inocula was confirmed by placing 3-g subsamples onto NARH agar, and also into a Petri dish containing DI water, before incubation at room temperature in the dark.

Seed of E. loxophleba subsp. gratiae were grown in 10-cell trays ( $90 \mathrm{ml} / \mathrm{cell}$; Garden City Plastics) containing sterilized, washed river sand. At the time of sowing, seed were placed in random cells of the trays and two holes were made in the sand at the center of each cell, one for seed and one for a 10-mm plastic tube placed for later inoculum delivery. After 2 months, the seedlings were inoculated with $2.5 \mathrm{~g}$ of inoculated vermiculite and covered with a thin layer of sand. They were harvested at 4 months old, allowed to dry at room temperature, and checked microscopically for the presence of oospores inside the roots using staining. Briefly, the root samples (1 to $2 \mathrm{~g}$ ) fixed in $50 \% \mathrm{EtOH}$ were rinsed with water, cleared by heating in $10 \%(\mathrm{wt} / \mathrm{vol}) \mathrm{KOH}$ in an autoclave, stained with $0.05 \%(\mathrm{wt} / \mathrm{vol})$ trypan blue, and destained with lactoglycerol (Brundrett et al. 1996).

Root pieces were also plated on NARH. Root pieces (5 to $10 \mathrm{~mm}$ ) containing oospores were placed in glass Petri dishes, then heated in an oven at $20,37.5,65,80$, and $95^{\circ} \mathrm{C}$ for $30,60,120$, and $240 \mathrm{~min}$. Dry conditions were simulated by leaving Petri dishes unsealed, while moist conditions were created by placing moist filter paper in the bottom of the dish and sealing with Parafilm. After treatment, root pieces were plated on NARH and incubated in the dark at $20^{\circ} \mathrm{C}$. There were three replicates of 10 root pieces per treatment. Plates were observed daily for colony growth.

Susceptibility of plant species to $\boldsymbol{P}$. boodjera. To determine host susceptibility to $P$. boodjera, seed of E. polybractea R. Baker, E. kochii subsp. plenissima (C. A. Gardiner) Booker, E. loxophleba subsp. gratiae, Melaleuca atroviride, and Cytisus proliferus (Tagasaste) were germinated in used container substrate in used 90-cell trays (utilizing the middle section only, 15 cells) taken from benches where mortality had been observed. This glasshouse trial was conducted at Murdoch University with six replicate trays per plant species containing 20 to 25 seeds/cell. Seed of all species germinated between 7 and 20 days. After 12 weeks, plants were harvested, roots were examined for necrotic lesions and plated on NARH, and disease incidence and severity were recorded. Disease incidence for each plant species was calculated as the percentage of cells with diseased seedlings, and disease severity in all seedlings within each cell was rated as $0=0,1=1$ to $25,2=$ 26 to $50,3=51$ to 75 , and $4=76$ to $100 \%$ of cells affected.

Susceptibility and effect of waterlogging on disease expression. Simamora et al. (2017) showed that $P$. boodjera is a damping-off

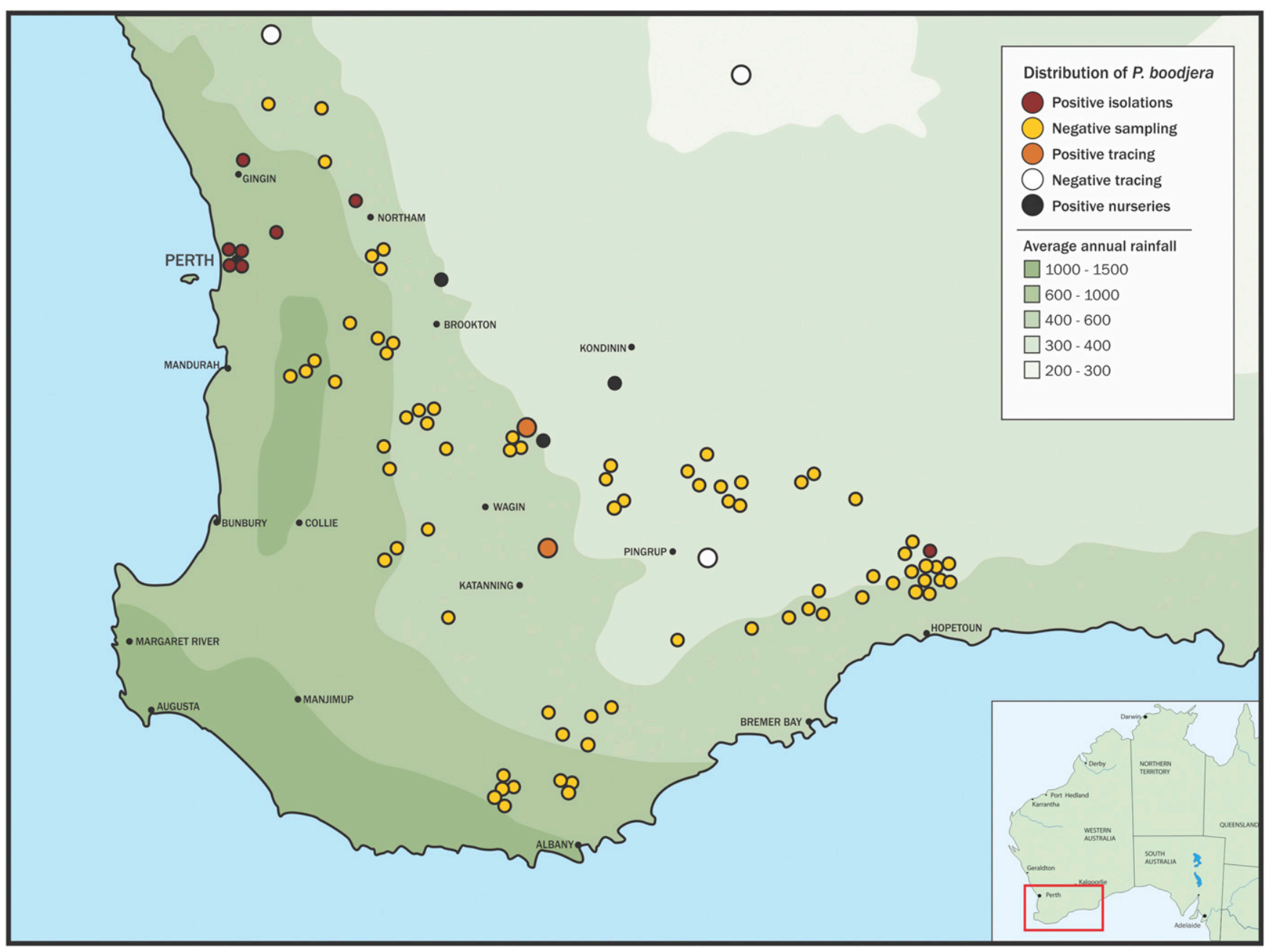

Fig. 2. Distribution of Phytophthora boodjera from the tracing study of infected plants, out-planted from a nursery, and as detected by targeted soil sampling from natural vegetation remnants. 
pathogen of mallee eucalypts under freely draining conditions. In the nursery, seedlings showed more severe damping-off in trays where the cells were not free draining (shelving bars here blocked drainage holes in the trays). To determine whether waterlogging increased the potential for disease, duplicate trials to those presented by Simamora et al. (2017) were carried out, where the trays were placed in larger trays permanently containing water, with the remainder of trays free draining.

Five species of mallees (E. polybractea, E. kochii subsp. plenissima, E. kochii subsp. borealis, E. loxophleba subsp. lissophloia, and two seedlots of E. loxophleba subsp. gratiae) were inoculated with four Phytophthora isolates ( $P$. boodjera isolates VHS 26806, VHS 27382, and PAB 11.56 and P. cinnamomi Rands MP94-48).

The sand container substrate and trays $(90 \mathrm{ml} / \mathrm{cell}$; Garden City Plastics) were pasteurized with steam for $1 \mathrm{~h}$ at $65^{\circ} \mathrm{C}$. The trays containing seedlings were arranged in a randomized complete block design and watered daily with DI water and fertilized weekly with water-soluble nutrients (Thrive; Yates Company) at $2 \mathrm{~g}$ per 5 liters. At the time of sowing, seed were placed in random cells of the trays and two holes were made in the sand at the center of each cell. Into one cell, 20 to 25 seeds were placed, and the vermiculite inocula ( $2.5 \mathrm{~g}=1 \%$ of sand volume) were placed into the second hole and covered with a thin layer of sand. For a second experiment, seedlings were inoculated at 14 days via a tube placed at sowing time next to the seed, which was removed for inoculation.

The number of surviving seedlings was recorded at the termination of the trial. For each experiment, a one-way analysis of variance was performed in SPSS to analyze the response of each eucalypt species to infestation by the different Phytophthora isolates for each inoculum time and each watering treatment. Roots were examined for necrotic lesions and plated on NARH.

Tracing of infected plants from the nursery. To determine whether the pathogen can be recovered from established environmental plantings of seedlings from this nursery, in 2014, roots and soil were collected from five areas planted in the 2011 and 2012

Table 2. Detection of Phytophthora boodjera following steam pasteurization of seedling trays with and without container substrate

\begin{tabular}{lcc}
\hline Sample & $\begin{array}{c}\text { Pasteurization } \\
\text { runs }\end{array}$ & $\begin{array}{c}\text { Number infested/number } \\
\text { treated }\end{array}$ \\
\hline Tray & 0 & $9 / 10$ \\
Container mix & 0 & $0 / 5$ \\
Tray & 1 & $0 / 10$ \\
Tray + container mix & 1 & $0 / 10$ \\
Tray & 2 & $0 / 10$ \\
Tray + container mix & 2 & $0 / 10$ \\
\hline
\end{tabular}

seasons: Toolibin Lake (north of Wagin), 12 samples; Lake Bryde (east of Pingrup), 12 samples; Morawa (north of Gin Gin), 9 samples; Bullfinch (northeast of Kondinin), 4 samples; and Badgebup (northeast of Katanning), 3 samples (Fig. 2). Roots and attached soil were sampled from the rhizosphere of both dying and healthy plants. Each sample consisted of four to seven subsamples (300 to $500 \mathrm{~g}$ ) from adjacent, separate plants taken at a depth of 20 to $30 \mathrm{~cm}$. Subsamples were bulked together and kept dry and cool (4 to 12 samples/ site). To detect Phytophthora spp., a double baiting method was used. If no recoveries were made after the first round of baiting, the water was decanted and the soil dried for 3 weeks; then. baiting was repeated to induce germination of dormant spores to increase the likelihood of detection.

Targeted sampling in natural remnants. Further sampling targeted areas of environmental plantings and eucalypt plantations in the wheatbelt region of Western Australia. Seventy-one soil samples from asymptomatic plants within natural vegetation remnants were collected (Fig. 2). All soil and root samples were collected from at least $20 \mathrm{~m}$ away from any obvious disturbance (such as roads or drains), except for one isolate collected from roadside remnant vegetation in Northam. In addition, samples were taken from other nurseries in the same region. The same double-baiting method was used as described above.

\section{Results}

On-site sampling. All water supplies used in the nursery were clean; therefore, P. boodjera was already present in the production area because it was detected in the drainage water (site 10; Table 1), and further confirmed as present in soil samples from under the production benches (but only during the growing season). P. boodjera was also detected in all material sampled adjacent to the nursery area (sites 3, 6, 7, 8 , and 9). The only equipment used in potting, storage, and handling with positive recoveries of $P$. boodjera was the used untreated trays. Some batches of eucalypt seedlings at different ages (2 weeks and 2 months old) were infected by $P$. boodjera. $P$. boodjera was not isolated from all other plant genera, ants, or fungal gnat larvae (Table 1).

Tray sterilization. Used untreated trays were infested with $P$. boodjera but the unused potting substrate was pathogen free (Table 2). One run of pasteurization was enough to eliminate $P$. boodjera in empty used untreated trays, and in trays containing potting mix.

The treatments used by the nursery (dry heat for 2 days, highpressure water cleaning, and soaking in biocide) were not as effective as tray cleaning treatments because $P$. boodjera was recovered from them as often as from untreated trays. In contrast, boiling of the trays for $15 \mathrm{~min}$ was effective in destroying $P$. boodjera.

New trays and boiled trays could be used for growing seedlings in the nursery because they were free of $P$. boodjera (Table 3). Different types

Table 3. Recoveries of Phytophthora boodjera from seedling trays containing different container substrates and using different sources of water

\begin{tabular}{|c|c|c|c|c|}
\hline Seed used & Tray type & Potting media ${ }^{y}$ & Water source ${ }^{\mathbf{z}}$ & P. boodjera recovery \\
\hline Eucalyptus loxophleba subsp. gratiae & New & Pine bark & RW & Negative \\
\hline E. loxophleba subsp. gratiae & New & Pine bark & TW & Negative \\
\hline E. loxophleba subsp. gratiae & New & Pine bark & NRW & Negative \\
\hline E. loxophleba subsp. gratiae & New & DPaW PM & RW & Negative \\
\hline E. loxophleba subsp. gratiae & New & DPaW PM & TW & Negative \\
\hline E. loxophleba subsp. gratiae & New & DPaW PM & NRW & Negative \\
\hline E. loxophleba subsp. gratiae & Boiled & Pine bark & RW & Negative \\
\hline E. loxophleba subsp. gratiae & Boiled & Pine bark & TW & Negative \\
\hline E. loxophleba subsp. gratiae & Boiled & DPaW PM & RW & Negative \\
\hline E. loxophleba subsp. gratiae & Boiled & DPaW PM & TW & Negative \\
\hline E. loxophleba subsp. gratiae & Used & Pine bark & RW & Positive \\
\hline E. loxophleba subsp. gratiae & Used & Pine bark & $\mathrm{TW}$ & Positive \\
\hline E. loxophleba subsp. gratiae & Used & DPaW PM & RW & Positive \\
\hline E. loxophleba subsp. gratiae & Used & DPaW PM & TW & Positive \\
\hline Banksia occidentalis & New & Pine bark & TW & Negative \\
\hline B. occidentalis & New & DPaW PM & TW & Negative \\
\hline B. occidentalis & Used & Pine bark & TW & Positive \\
\hline B. occidentalis & Used & DPaW PM & TW & Negative \\
\hline
\end{tabular}

${ }^{y}$ DPaW PM = standard container substrate used by the Department of Parks and Wildlife for glasshouse trials.

${ }^{\mathrm{z}} \mathrm{RW}=$ rain water obtained from off-site, $\mathrm{TW}=$ nursery tank water, and NRW = nursery rain water. 
of container substrate (pine bark from the nursery and $\mathrm{DPaW}$ ) were not the source of $P$. boodjera inoculum in the nursery (Table 3 ). Off-site rain water, nursery tank water, and nursery rainwater were also free of $P$. boodjera and were safe to be used (Table 3 ). Disease was only observed, and $P$. boodjera only recovered, from used untreated trays.

Heat treating infected roots (oospores). $P$. boodjera was not recovered from infected roots subjected to all exposure times above $65^{\circ} \mathrm{C}$ (moist or dry), while moist heat of $65^{\circ} \mathrm{C}$ for at least $1 \mathrm{~h}$ eradicated the pathogen (Table 4).

Host susceptibility. The Eucalyptus spp. were significantly more affected by $P$. boodjera than the Melaluca sp. and $C$. proliferus. Damping-off symptoms were first seen at day 15, when some seedlings started to wilt, then yellowed and died within 5 days (Table 5). E. polybractea seedlings had significantly lower mortality and severity ratings than E. kochii subsp. plenissima and E. loxophleba subsp. gratiae. All M. atroviride and C. proliferus seedlings remained healthy for the duration of the trial (Table 5).

Susceptibility and waterlogging. Eucalyptus seed germinated within 7 to 14 days, with an average rate of $80 \%$ for all eucalypt species tested. When inoculated before emergence, there was no difference in seedling survival between the constant water and freedraining treatments but, for all treatments, seedling survival was significantly $(P<0.05)$ lower than in noninoculated controls (Supplementary Table $\mathrm{S} 1)$.

Tracing of $\boldsymbol{P}$. boodjera from the nursery. $P$. boodjera has been recovered from three nurseries (Fig. 2). For tracing studies, P. boodjera was recovered in 2014 from three samples from trees out-planted in 2011 or 2012 around Toolibin Lake and one sample from Badgebup. It was not recovered from plantings at Lake Bryde, Bullfinch, or Morawa (Fig. 2).

Detection of $\boldsymbol{P}$. boodjera from remnant vegetation. $P$. boodjera was recovered from asymptomatic plants in only 1 of the 71 sampled sites. This recovery was made in Northam, in a remnant stand of eucalypt trees on the edge of the highway (Fig. 2). It had previously been recovered from a dying Banksia specimen on a road verge near Ravensthorpe, near the south coast (Simamora et al. 2015), but additional sampling in the region did not result in any more recoveries. $P$. boodjera has been detected in routine sampling of declining trees in urban parks and from reserves in the peri-urban areas around Perth (Simamora et al. 2015) (Fig. 2). A complete list of isolates of $P$. boodjera from Western Australia is provided in Supplementary Table S2.

\section{Discussion}

During a detailed analysis of the infection sources and pathways in a single nursery where production of eucalypt seedlings had been debilitated by $P$. boodjera infestation, we were able to demonstrate that this pathogen was not killed by the nursery's standard hygiene practices. P. boodjera caused higher mortality in seedlings of these eucalypt species than a highly pathogenic isolate of $P$. cinnamomi. Also, $P$. boodjera appears to have survived out-planting in the revegetation sites. These findings are of great concern for nurseries, plantations, revegetation projects, and urban areas as the host range and survival capability of $P$. boodjera have not been investigated.

$P$. boodjera persisted on site in the nursery and reinfected young seedlings in subsequent years. Extensive on-site sampling recovered the pathogen from the lawn and the roots of eucalypt hedgerow plantings adjacent to the nursery benches, and from soil under the benches (which was presumably contaminated by the $P$. boodjera zoospores from trays and pots on the benches during irrigation). However, the source of reinfestation between years was root debris containing oospores adhering to the sides of the used potting trays. Although used trays were always sterilized in 5\% chlorine (calcium hypochlorite) solution, due to residual organic material, the active agent would not have been maintained for the necessary retention period and, thus, was unable to eradicate the pathogen.

Oospores generally are resistant to desiccation, cold temperatures, and other extreme environmental conditions, and can survive in the soil for several years in the absence of a host plant (Erwin and Ribeiro 1996; Hausbeck and Lamour 2004). This study found that oospores of $P$. boodjera were profusely formed in infected roots of the eucalypt seedlings, and it has been suggested that this mechanism promotes long-term survival in harsh natural environments (Crone et al. 2013; Mircetich and Zentmyer 1966). P. boodjera did not survive during the nursery's fallow or dry season in the untreated soil under the production benches, probably due to the absence of host material. However, the inoculum did survive over the fallow period on root fragments attached to used seedling trays. Oospores were completely inactivated after $60 \mathrm{~min}$ at $65^{\circ} \mathrm{C}$ in a moist heat treatment, and after $30 \mathrm{~min}$ at $80^{\circ} \mathrm{C}$ in a dry heat treatment. A dry treatment of $50^{\circ} \mathrm{C}$ for $120 \mathrm{~min}$ was required for inactivation of $P$. ramorum in soil medium (Schweigkofler et al. 2014) whereas $P$. cinnamomi required $30 \mathrm{~min}$ at $75^{\circ} \mathrm{C}$ in a steam treatment (de Jager and Kotzé 1994), indicating the need for comprehensive testing of sterilization techniques for a range of species to determine the optimal standards necessary for industry.

$P$. boodjera in the nursery lawn, and in soil under the nearby trees and hedgerow trees, presents a continual risk to the nursery, as well as the chance of workers spreading the pathogen offsite. Thus, it is important to consider strict hygiene methods or quarantine of these areas. Monitoring areas outside the current infection range to detect any expansion of the known infestation area (Tkacz et al. 2006), determine inoculum loads (Hulvey et al. 2010; Reeser et al. 2011), and evaluate the success of any eradication activities (Filipe et al. 2012; Kanaskie et al. 2011) are of utmost importance to reduce the spread of the pathogen and ensure the future of the business.

Waterlogging in the glasshouse did not increase the infection rate of $P$. boodjera on eucalypt seedlings. This is contrary to the studies on $P$. cinnamomi, where waterlogged situations increase the potential for infection by enabling zoospores to move freely while creating stressful hypoxic conditions for plant roots (Burgess et al. 1999; Davison 1988; Hardy et al. 1996; O'Gara et al. 1997). Seedling survival postinoculation with $P$. boodjera was better for waterlogged seedlings than those in free-draining conditions; under waterlogged conditions, some seedlings survived with damaged root systems, whereas, if free draining, more seedlings wilted and died. However, these results may not extrapolate to the natural environment or hold for older plants; thus, further testing of this pathogen is required to understand the effect of water availability on the infection process.

$P$. boodjera infected all Eucalyptus spp. tested, and they were more susceptible when inoculated prior to emergence rather than

Table 4. Recovery of Phytophthora boodjera from infected root pieces after treatment with steam pasteurization (moist) or dry heat $(+=$ positive recovery and $-=$ no recovery)

\begin{tabular}{|c|c|c|c|c|c|c|c|c|}
\hline \multirow[b]{3}{*}{ Temperature $\left({ }^{\circ} \mathrm{C}\right)$} & \multicolumn{8}{|c|}{ Time of exposure (min) } \\
\hline & \multicolumn{2}{|c|}{30} & \multicolumn{2}{|c|}{60} & \multicolumn{2}{|c|}{120} & \multicolumn{2}{|c|}{240} \\
\hline & Moist & Dry & Moist & Dry & Moist & Dry & Moist & $\overline{\text { Dry }}$ \\
\hline 20 & + & + & + & + & + & + & + & + \\
\hline 37.5 & + & + & + & + & + & + & + & + \\
\hline 65 & + & + & - & + & - & + & - & + \\
\hline 80 & - & - & - & - & - & - & - & - \\
\hline 95 & - & - & - & - & - & - & - & - \\
\hline
\end{tabular}

Table 5. Percentage of seedling tray cells with dead seedlings (Mortality) and the disease severity (DS) of affected cells in nursery seedlings inoculated with Phytophthora boodjera ${ }^{\mathrm{z}}$

\begin{tabular}{lcc}
\hline Plant species & $\begin{array}{c}\text { Mortality (\%) } \pm \\
\text { SE }\end{array}$ & $\begin{array}{c}\text { DS (rating) } \\
\mathbf{\pm S E}\end{array}$ \\
\hline $\begin{array}{l}\text { Eucalyptus kochii } \text { subsp. } \\
\text { plenissima }\end{array}$ & $22.67 \pm 3.61 \mathrm{a}$ & $1.83 \pm 0.30 \mathrm{a}$ \\
E. loxophleba subsp. gratiae & $15.33 \pm 3.45 \mathrm{a}$ & $1.74 \pm 0.35 \mathrm{a}$ \\
E. polybractea & $8.67 \pm 2.00 \mathrm{~b}$ & $1.44 \pm 0.35 \mathrm{~b}$ \\
Melaleuca spp. & $0 \mathrm{c}$ & $0 \mathrm{c}$ \\
Cytisus proliferus & $0 \mathrm{c}$ & $0 \mathrm{c}$ \\
\hline
\end{tabular}

${ }^{\mathrm{z}}$ Disease severity was rated as $0=$ all healthy and $1=1$ to $25,2=26$ to $50,3=$ 51 to 75 , and $4=76$ to $100 \%$ of cells affected. Numbers in columns followed by the same letter are not significantly different. $\mathrm{SE}=$ standard error. 
postemergence. In the nursery, the seedlings became infected and died when they reached the four- to six-leaf stage (approximately 2 months old). This is probably because the inoculum load in the trays was initially very low and only immediately after the germination of seedlings did the infection process commence, leading to increased inoculum levels in the trays over time. Eucalyptus spp. were the main host of $P$. boodjera in the nursery and the pathogen was not isolated from other plant genera. However, it has been isolated in association with declining Agonis flexuosa, Banksia spp., Corymbia calophylla, C. ficifolia, and Xanthorrhoea preissii from other locations (Simamora et al. 2015). Understanding what determines a pathogen's host range and the potential for host shifts is of critical importance in controlling its introduction into new environments (De Vienne et al. 2009). Recently introduced exotic species are the greatest concern in the nursery trade because they may escape detection, resulting in an expanded geographical range when out-planted (Parke et al. 2014). More information is required on the potential Australian hosts of $P$. boodjera and its ability to survive in the environment.

$P$. boodjera survived in two locations where eucalypt seedlings from this nursery had been planted 3 to 4 years earlier. The low frequency of its recovery is probably due to low levels of inoculum present. This pathogen functions as a pre- and postemergent dampingoff pathogen of young seedlings ( 0 to 4 weeks old), where it reduces root biomass, and the damage it causes decreases with the age of the plant (Simamora et al. 2017). Because the trees were greater than 3 years old, it is likely that inoculum levels at these sites were low by this time. Some newly introduced Phytophthora spp. initially have a patchy distribution of inoculum but can have a large effect on the subsequent pattern of disease when conditions for proliferation are conducive (Ristaino and Gumpertz 2000). Because P. boodjera is a damping-off pathogen, its continued presence postplanting may affect regeneration and seedling recruitment and drive long-term vegetation shifts (Ibáñez et al. 2015; Suarez and Kitzberger 2008).

Currently, our knowledge of the geographic distribution and host range of $P$. boodjera is limited, and the consequence of this new introduction is unknown. Because $P$. boodjera has the potential to be devastating to eucalypt production and revegetation projects, we must improve our diagnostic and management capability. The survival mechanisms of $P$. boodjera in both the glasshouse and the natural environment and oospore survival under different soil water potentials need to be understood, along with the survival ability of the various propagules at different soil depths and within host material across seasons. The optimum baits need to be identified as well as the development of specific molecular probes with primers to identify $P$. boodjera in soil, regardless of its environmental conditions and dormancy. The susceptibility of $P$. boodjera to chemicals such as phosphite and the optimum treatment for decreasing damage caused by $P$. boodjera also need to be verified.

In Europe, the plant trade has been identified as a key introduction pathway for invasive pathogens (Santini et al. 2013). In the United States, there are many reports of Phytophthora spp. in nurseries. For instance, Bienapfl and Balci (2014) reported finding 16 species in Maryland, while Parke et al. (2014) found 28 different species or taxa in Oregon nurseries. Bienapfl and Balci (2014) provided an additional 15 references from the United States and Australia, demonstrating the potential for the ongoing introduction of Phytophthora spp. into the environment from these nurseries. In an appraisal of nursery industry protocols for the control of Phytophthora spp. in Australia, Hancock (2015) concluded that current nursery industry advice is not sufficient to address the threat to Australian flora posed by Phytophthora spp. from nursery stock, particularly for the supply of plant material to conservation areas. There needs to be a higher standard for Phytophthora control and there should be a system developed by which nurseries can be cleared after positive Phytophthora spp. testing (Hancock 2015). Supporting this, a dual-stage cleaning process was recommended for used containers, including steam sterilization and hot washes $\left(80^{\circ} \mathrm{C}\right)$. This recommendation is supported by the current study.

This extensive examination of sources of nursery contamination for $P$. boodjera has made a major contribution to our understanding of this newly recorded pre- and postemergent damping-off disease of eucalypts in a plant production nursery, including its pathogenicity and epidemiology. These findings will help managers and scientists to understand aspects of damping-off disease in other eucalypt and plant species in nurseries and are likely to be applicable to all soilborne oomycetes and other pathogens. Early detection, in addition to identification of the pathways of Phytophthora infection and spread, are of high importance to minimize the threat posed to natural ecosystems, because emerging pathogens can result in disease epidemics which can be ecologically and economically difficult to manage (Hyun and Choi 2014; Scott et al. 2013). In all countries, the risk of any outbreak can result from poor hygiene in a single nursery, limiting the success of biosecurity efforts (Bate et al. 2016) as well as damaging conservation efforts.

\section{Acknowledgments}

We thank K. Parnell and B. Copestake at Parnells Nursery in Tincurrin for their continued support of the project over several years, and P. White and J. Bartle of Western Australia DPaW, who alerted us to the disease when they collected the first nursery and field samples, leading to this study. A. Simamora thanks DIKTI program from the Indonesian Government for a Ph.D. scholarship.

\section{Literature Cited}

Bate, A. M., Jones, G., Kleczkowski, A., Macleod, A., Timmis, J., Touza, J., and White, P. C. L. 2016. Modelling the impact and control of an infectious disease in a plant nursery with infected plant material inputs. Ecol. Modell. 334:27-43

Bienapfl, J. C., and Balci, Y. 2014. Movement of Phytophthora spp. in Maryland's nursery trade. Plant Dis. 98:134-144.

Brasier, C. M. 2008. The biosecurity threat to the UK and global environment from international trade in plants. Plant Pathol. 57:792-808.

Brundrett, M., Bougher, N., Dell, B., Grove, T., and Malajczuk, N. 1996. Working with Mycorrhizas in Forestry and Agriculture. ACIAR Monogr. 32. Australian Centre for International Agricultural Research, Canberra, ACT, Australia.

Burgess, T., McComb, J. A., Colquhoun, I., and Hardy, G. E. St. J. 1999. Increased susceptibility of Eucalyptus marginata to stem infection by Phytophthora cinnamomi resulting from root hypoxia. Plant Pathol. 48:797-806.

Crone, M., McComb, J. A., O’Brien, P. A., and Hardy, G. E. St. J. 2013. Survival of Phytophthora cinnamomi as oospores, stromata, and thick-walled chlamydospores in roots of symptomatic and asymptomatic annual and herbaceous perennial plant species. Fungal Biol. 117:112-123.

Davison, E. M. 1988. The role of waterlogging and Phytophthora cinnamomi in the decline and death of Eucalyptus marginata in Western Australia. GeoJournal 17:239-244.

Davison, E. M., Drenth, A., Kumar, S., Mack, S., Mackie, A. E., and McKirdy, S 2006. Pathogens associated with nursery plants imported into Western Australia. Australas. Plant Pathol. 35:473-475.

de Jager, I., and Kotzé, J. M. 1994. Steam pasteurisation as an alternative to fumigation for disinfecting container media. S. Afr. Avocado Grow. Assoc. Yearb. 17:59-63.

De Vienne, D. M., Hood, M. E., and Giraud, T. 2009. Phylogenetic determinants of potential host shifts in fungal pathogens. J. Evol. Biol. 22:2532-2541.

Erwin, D. C., and Ribeiro, O. K. 1996. Phytophthora Diseases Worldwide. American Phytopathological Society Press, St Paul, MN.

Filipe, J. A. N., Cobb, R. C., Meentemeyer, R. K., Lee, C. A., Valachovic, Y. S., Cook, A. R., Rizzo, D. M., and Gilligan, A. 2012. Landscape epidemiology and control of pathogens with cryptic and long distance dispersal: Sudden oak death in Northern Californian forests. PLOS Comput. Biol. 8:e1002328.

Hancock, D. J. 2015. Towards new nursery industry protocols for Phytophthora control: Supply of stock for restoration and vegetation. Australas. Plant Conserv. 23:13-15.

Hardy, G. E., and Sivasithamparam, K. 1988. Phytophthora spp. associated with container-grown plants in nurseries in Western Australia. Plant Dis. 72: 435-437.

Hardy, G. E. St. J., Colquhoun, I. J., and Nielsen, P. 1996. The early development of disease caused by Phytophthora cinnamomi in Eucalyptus marginata and Eucalyptus calophylla growing in rehabilitated bauxite mined areas. Plant Pathol. 45:944-954.

Hausbeck, M. K., and Lamour, K. H. 2004. Phytophthora capsici on vegetable crops: Research progress and management challenges. Plant Dis. 88:1292-1303.

Hulvey, J., Gobena, D., Finley, L., and Lamour, K. H. 2010. Co-occurrence and genotypic distribution of Phytophthora species recovered from watersheds and plant nurseries of eastern Tennessee. Mycologia 102:1127-1133.

Hyun, I.-H., and Choi, W. 2014. Phytophthora species, new threats to plant health in Korea. Plant Pathol. 30:331-342.

Ibáñez, B., Gómez-Aparicio, L., Stoll, P., Ávila, J. M., Pérez-Ramos, I. M., and Marañón, T. 2015. A neighborhood analysis of the consequences of Quercus suber decline for regeneration dynamics in Mediterranean Forests. PLoS One 10:e0117827.

Jung, T., Orlikowski, L., Henricot, B., Abad-Campos, P., Aday, A. G., Aguin Casal, O., Bakonyi, J., Cacciola, S. O., Cech, T., Chavarriaga, D., Corcobado, T., Cravador, A., Decourcelle, T., Denton, G., Diamandis, S., 
Dogmus-Lehtijarvi, H. T., Franceschini, A., Ginetti, B., Green, S., Glavendekic, M., Hantula, J., Hartmann, G., Herrero, M., Ivic, D., Horta Jung, M., Lilja, A., Keca, N., Kramarets, V., Lyubenova, A., Machado, H., Magnano di San Lio, G., Mansilla Vazquez, P. J., Marcais, B., Matsiakh, I., Milenkovic, I., Moricca, S., Nagy, Z. A., Nechwatal, J., Olsson, C., Oszako, T., Pane, A., Paplomatas, E. J., Pintos Varela, C., Prospero, S., Rial Martınez, C., Rigling, D., Robin, C., Rytkonen, A., Sanchez, M. E., Sanz Ros, A. V., Scanu, B., Schlenzig, A., Schumacher, J., Slavov, S., Solla, A., Sousa, E., Stenlid, J., Talgø, V., Tomic, Z., Tsopelas, P., Vannini, A., Vettraino, A. M., Wenneker, M., Woodward, S., and Perez-Sierra, A. 2016. Widespread Phytophthora infestations in European nurseries put forest, seminatural and horticultural ecosystems at high risk of Phytophthora diseases. For. Pathol. 46:134-163.

Kanaskie, A., Hansen, E., Goheen, E. M., Osterbauer, N., McWilliams, M., Laine, J., Thompson, M., Savona, S., Timeus, H., Woosley, B., Sutton, W., Reeser, P., Schultz, R., and Hilburn, D. 2011. Progress of the Phytophthora ramorum eradication programme in south-western Oregon forests, 2001-2009. N. Z. J. For. Sci. 41:S169-175.

Matheron, M. E., and Mircetich, S. M. 1985. Pathogenicity and relative virulence of Phytophthora spp. from walnut and other plants to rootstocks of English walnut trees. Phytopathol. 75:977-981.

Mircetich, S. M., and Zentmyer, G. A. 1966. Production of oospores and chlamydospores of Phytophthora cinnamomi in roots and soil. Phytopathology 56:1076-1078.

NIASA. 2013. Best Management Practice Guidelines, 5th ed. Nursery and Garden Industry Australia, Sydney, New South Wales.

O'Gara, E., McComb, J. A., Colquhoun, I., and Hardy, G. E. St. J. 1997. The infection of non-wounded and wounded periderm tissue at the lower stem of Eucalyptus marginata by zoospores of Phytophthora cinnamomi, in a rehabilitated bauxite mine. Australas. Plant Pathol. 26:135-141.

Parke, J. L., and Grünwald, N. J. 2012. A systems approach for management of pests and pathogens of nursery crops. Plant Dis. 96:1236-1244.

Parke, J. L., Knaus, B. J., Fieland, V. J., Lewis, C., and Grünwald, N. J. 2014. Phytophthora community structure analyses in Oregon nurseries inform systems approaches to disease management. Phytopathology 104:1052-1062.
Pérez-Sierra, A., and Jung, T. 2013. Phytophthora in woody ornamental nurseries. Pages 166-177 in: Phytophthora: A Global Perspective. K. Lamour, ed. CAB International, Wallingford, UK.

Reeser, P. W., Sutton, W., Hansen, E. M., Remigi, P., and Adams, G. C. 2011 Phytophthora species in forest streams in Oregon and Alaska. Mycologia 103:22-35.

Ristaino, J. B., and Gumpertz, M. L. 2000. New frontiers in the study of dispersa and spatial analysis of epidemics caused by species of the genus Phytophthora. Annu. Rev. Phytopathol. 38:541-576.

Santini, A., Ghelardini, L., De Pace, C., Desprez-Loustau, M. L., Capretti, P. Chandelier, A., Cech, T., Chira, D., Diamandis, S., Gaitniekis, T., Hantula, J., Holdenrieder, O., Jankovsky, L., Jung, T., Jurc, D., Kirisits, T., Kunca, A., Lygis, V., Malecka, M., Marcais, B., Schmitz, S., Schumacher, J., Solheim, H., Solla, A., Szabò, I., Tsopelas, P., Vannini, A., Vettraino, A. M., Webber, J., Woodward, S., and Stenlid, J. 2013. Biogeographical patterns and determinants of invasion by forest pathogens in Europe. New Phytol. 197:238-250.

Schweigkofler, W., Kosta, K., Huffman, V., Sharma, S., Suslow, K., and Ghosh, S 2014. Steaming inactivates Phytophthora ramorum, causal agent of sudden oak death and ramorum blight, from infested nursery soils in California. Plant Health Prog. 15:43-47.

Scott, P. M., Burgess, T. I., and Hardy, G. E. St. J. 2013. Globalization and Phytophthora. Pages 226-232 in: Phytophthora: A Global Perspective. K. Lamour, ed. CAB International, Wallingford, UK.

Simamora, A. V., Stukely, M. J. C., Barber, P. A., Hardy, G. E. St. J., and Burgess, T. I. 2017. Age-related susceptibility of Eucalyptus species to Phytophthora boodjera. Plant Pathol. 66:501-512

Simamora, A. V., Stukely, M. J. C., Hardy, G. E. St. J., and Burgess, T. I. 2015 Phytophthora boodjera sp. nov., a damping-off pathogen in production nurseries and from urban and natural landscapes, with an update status of $P$. alticola. IMA Fungus 6:319-335.

Suarez, M. L., and Kitzberger, T. 2008. Recruitment patterns following a severe drought: Long-term compositional shifts in Patagonian forests. Can. J. For. Res. 38:3002-3010.

Tkacz, B. M., Oak, S. W., and Smith, W. D. 2006. National detection surveys for sudden oak death. In: Proc. Sixth Annu. For. Inventory Anal. Symp. Denver CO. Gen. Tech. Rep. U.S. Dep. Agric. For. Serv. 1260. WO-70. Washington, DC 